\title{
PENGUJIAN KAPANG DAN BAKTERI PATOGEN PADA IKAN KAYU (KATSUOBUSHI) ASAP CAIR SELAMA PENYIMPANAN
}

\author{
Annissa Iqlima Nurrohman ${ }^{1}$, Henny Adeleida Dien ${ }^{2}$, Josefa T. Kaparang ${ }^{2}$, \\ Agnes T. Agustin ${ }^{2}$, Semuel M. Timbowo ${ }^{2}$, Daisy M. Makapedua ${ }^{2}$ Grace Sanger $^{2}$ \\ ${ }^{1}$ Mahasiswa pada Program Studi Teknologi Hasil Perikanan FPIK UNSRAT Manado. \\ ${ }^{2}$ Staf Pengajar pada Program Studi Teknologi Hasil Perikanan FPIK UNSRAT Manado.
}

\begin{abstract}
Wooden fish products that are usually processed traditionally have a weakness, namely deposit of tar in food ingredients which endangers health and air pollution that is not environmentally friendly. Today's wood processing is the high content of Polycyclic Aromatic Hydrocarbons (PAH), especially benzopirene which can cause cancer, as an alternative to wood fish processing conducted research using liquid smoke wood fogging technology. The purpose of this study is to calculate the presence of molds and pathogenic bacteria that can contaminate processed fishery products, namely wood fish. The microbial test results showed that the mold value in the lowest range was $2.0 \times 10^{2}$ on day 0 with a concentration of $4 \%$ soaking 30 minutes and the highest value was $1.4 \times 10^{3}$ on the $30^{\text {th }}$ day with a concentration of $2 \%$ immersion 120 minutes. The total plate number of fresh skipjack with a value of $5.8 \times 10^{4} \mathrm{cfu} / \mathrm{gram}$ and after being processed into wood fish the lowest ALT value is $2.9 \times 10^{2} \mathrm{cfu} / \mathrm{gram}$ on day 0 with a concentration of $2 \% 120$ minutes soaking and a high value of $9.9 \times 10^{2} \mathrm{cfu} / \mathrm{gram}$ on the $30^{\text {th }}$ day with a concentration of $8 \%$ soaking 30 minutes, testing of pathogenic bacteria showed negative results (none). Chemical testing showed that the lowest water content value was $13 \%$ on day 0 with a concentration of $6 \%$ and the highest value was $17.25 \%$ on day 30 concentration of $2 \%$ soaking and 120 minutes. The lowest $\mathrm{pH}$ value is 5.38 on day 0 with a concentration of $2 \% 120$ minutes soaking and the highest value is 5.96 on day 15 with a concentration of $2 \%$ soaking 30 minutes. The test results showed significant results in the ANOVA test.
\end{abstract}

Keyword: Wood Fish, Liquid Smoke, Microbes.

Produk ikan kayu yang biasa diolah secara tradisional memiliki kelemahan yaitu terdepositnya tar pada bahan makanan sehingga membahayakan kesehatan serta adanya polusi udara yang tidak ramah lingkungan. Pengolahan ikan kayu dewasa ini adalah tingginya kandungan senyawa Polycyclic Aromatic Hydrocarbon $(\mathrm{PAH})$ terutama benzopiren yang dapat menyebabkan kanker, sebagai alternatif dalam pengolahan ikan kayu dilakukan penelitian menggunakan teknologi pengasapan ikan kayu asap cair. Tujuan penelitian ini untuk menghitung keberadaan kapang dan bakteri patogen yang dapat mengkontaminasi produk olahan hasil perikanan yaitu ikan kayu. Hasil pengujian mikroba menunjukkan bahwa nilai kapang pada range paling terendah yaitu $2,0 \times 10^{2}$ pada hari ke 0 dengan konsentrasi $4 \%$ perendaman 30 menit dan nilai tertinggi yaitu $1,4 \times 10^{3}$ pada hari ke 30 dengan konsentrasi $2 \%$ perendaman 120 menit. Angka Lempeng total ikan cakalang segar dengan nilai 5,8 $\times 10^{4} \mathrm{cfu} / \mathrm{gram}$ dan setelah diolah menjadi ikan kayu nilai ALT terendah yaitu $2,9 \times 10^{2} \mathrm{cfu} / \mathrm{gram}$ pada hari ke 0 dengan konsentrasi $2 \%$ perendaman 120 menit dan nilai tertinggi yaitu $9,9 \times 10^{2}$ cfu/gram pada hari ke 30 dengan konsentrasi $8 \%$ perendaman 30 menit, pengujian bakteri patogen menunjukkan hasil negatif (tidak ada). Pengujian kimia, menunjukkan bahwa nilai kadar air yang terendah yaitu $13 \%$ pada hari ke 0 dengan konsentrasi $6 \%$ dan nilai tertinggi yaitu $17,25 \%$ pada hari ke 30 konsentrasi $2 \%$ perendaman dan 120 menit. Nilai $\mathrm{pH}$ yang terendah yaitu 5,38 pada hari ke 0 dengan konsentrasi $2 \%$ perendaman 120 menit dan nilai tertinggi yaitu 5,96 pada hari ke 15 dengan konsentrasi $2 \%$ perendaman 30 menit. Hasil uji menunjukkan signifikan pada uji anova.

Kata kunci: Ikan Kayu, Asap Cair, Mikroba.

\section{PENDAHULUAN}

Ikan kayu sering di negara Jepang dikenal dengan istilah Katsuobushi, salah satu produk olahan ikan asap yang dihasilkan oleh kombinasi proses perebusan dan pengasapan. Ikan kayu di Indonesia merupakan produk olahan ikan secara tradisional dan menjadi produk olahan dari berbagai daerah terutama di Sulawesi Utara, Sulawesi Selatan, Aceh serta beberapa daerah lainnya (Rahayu, 1991).

Proses pengolahan ikan kayu secara tradisional yaitu, penyiangan, perebusan, 
pencabutan tulang dan kepala, pengeringan dan pengasapan selama 7 hari. Pengolahan ikan kayu secara tradisional memiliki kelemahan yaitu terdepositnya tar pada daging ikan sehingga membahayakan kesehatan serta adanya polusi udara yang tidak ramah lingkungan. Asap dari hasil pengasapan selain mengandung komponen-komponen yang berfungsi sebagai bahan pengawet juga mengandung senyawa Polycyclic Aromatic Hydrocarbon (PAH) jenis benzopyrene yang merupakan senyawa karsinogenik penyebab kanker (Pszczola, 1995). Berhimpon et.al., 2003 juga menyatakan bahwa kelemahan ikan kayu yang ada di dunia dewasa ini adalah tingginya kandungan Polycyclic Aromatic Hydrocarbon (PAH) yang melebihi $10 \mathrm{ppb}$. Karena itu, perlu dicari teknologi baru untuk memproduksi ikan kayu yang rendah PAH. Adanya teknologi pengasapan dengan menggunakan asap cair sebagai alternatif dalam pengolahan ikan kayu dan juga bisa meminimalisir kandungan senyawa karsinogen pada ikan kayu. Hasil penelitian Berhimpon et.al., (2015) bahwa kandungan PAH pada asap cair yaitu $<0,25 \mathrm{ppb}$.

Menurut Sutin (2008), asap cair dapat digunakan sebagai pengawet makanan karena mengandung senyawa-senyawa antibakteri dan antioksidan. Asap cair juga mempunyai keunggulan yaitu mudah diterapkan, praktis dan ramah lingkungan.

Selain asap cair bersifat sebagai pengawet maka perlu diketahui juga mutu suatu bahan pangan, dalam hal ini ikan kayu asap cair melalui beberapa pengujian cemaran mikroba yaitu kapang, Angka Lempeng Total (ALT), pengujian keberadaan bakteri patogen, serta pengujian kadar air dan $\mathrm{pH}$.

\section{METODOLOGI PENELITIAN}

\section{Bahan dan Alat Bahan}

Ikan Cakalang segar sebanyak $10 \mathrm{Kg}$, asap cair (konsentrasi 2, 4, 6 dan 8\%), akuades, media nutrient agar, media $E$. coli broth, media Alkaline Pepton Water (APW), $\mathrm{NaCl}$ 0,9\%, media lactose broth, media potato dextro agar (PDA) dan alkohol $70 \%$.

\section{Alat}

Thermocouple, pisau, talenan, timbangan, wadah untuk ikan, lemari pengering plastik ziplock, spatula, gunting, tabung reaksi, tabung durham, tabung hach, rak tabung hach, erlenmeyer, gelas ukur $1000 \mathrm{ml}$, gelas beaker $500 \mathrm{ml}$ dan, $50 \mathrm{ml}$, cawan petri, inkubator, oven, baki, timbangan analitik, kompor gas, panci, bunsen, autoclave, balat magnetik stirrer, magnetik stirrer, laminar flow, pipet mikro, alumunium foil, plastik wrapping, tisu, kertas label, sipiritus, $\mathrm{pH}$ meter, botol semprot, gelas ukur $100 \mathrm{ml}$, mortal dan pastle, cawan porselen, desikator, dan penjepit.

\section{Prosedur Pembuatan Ikan Kayu (Katsuobushi) Asap Cair}

Pembuatan ikan kayu asap cair adalah ikan cakalang sebagai bahan baku kurang lebih sebanyak $10 \mathrm{~kg}$, pertama-tama dilakukan penyiangan dimana insang dan isi perut dikeluarkan. Kemudian ikan yang sudah disiangi, dicuci bersih lalu direbus selama 90 menit dengan temperatur perebusan $80-90^{\circ} \mathrm{C}$ (temperatur diukur dengan menggunakan thermocouple). Setelah perebusan, ikan didinginkan kurang lebih selama 30 menit lalu ikan difilet menjadi empat bagian. Ikan yang sudah difilet dilakukan pembersihan kulit dan pencabutan tulang, kemudian direndam dalam larutan asap cair dengan konsentrasi masingmasing $2 \%, 4 \%, 6 \%$ dan $8 \%$ selama $30,60,90$ dan 120 menit. Selanjutnya, ikan dikeringkan dalam oven pengering selama 2 jam pada temperatur $85^{\circ} \mathrm{C}$. Setelah pengeringan 2 jam pertama ikan dikeluarkan dan didiamkan selama 4 jam dan direndam kembali dalam larutan asap cair dengan konsentrasi dan lama perendaman yang sama, kemudian dikeringkan kembali pada temperatur $65^{\circ} \mathrm{C}$ selama 2 jam. Seterusnya, pengeringan dilakukan kurang lebih selama 7 jam kali hingga memperoleh kadar air yang diinginkan (antara 15-17\%). Produk ikan kayu yang sudah jadi, kemudian dianalisis di laboratorium dengan melakukan uji analisa kapang, analisa mikroba patogen, kadar air dan $\mathrm{pH}$.

\section{Parameter Pengamatan \\ Prosedur Analisis Total Koloni Kapang (Fardiaz, 1993 yang dimodifikasi)}

Semua peralatan yang digunakan dalam analisa mikrobiologi disterilkan dengan menggunakan autoclave pada suhu $121^{\circ} \mathrm{C}$ selama 15 menit dengan tekanan 15 psi. PDA disiapkan sebagai berikut: sejumlah 3,9 gram PDA ditambahkan pada $100 \mathrm{ml}$ akuades kemudian didihkan. Setelah itu disterilkan 
dalam autoclave pada suhu $121^{\circ} \mathrm{C}$ selama 15 menit dengan tekanan 15 psi. Siapkan tabung reaksi yang diberi kode I-III yang berisi masing-masing $9 \mathrm{ml} \mathrm{NaCl}$ 0,9\% kemudian disterilkan. Sampel diblender sampai halus, kemudian ditimbang sebanyak 10 gram dan dimasukkan ke dalam erlenmeyer $250 \mathrm{ml}$ berisi $90 \mathrm{ml}$ larutan $\mathrm{NaCl} 0,9 \%$ steril. Sampel ini merupakan pengenceran $10^{-1}$.Kemudian dari larutan tersebut diambil $1 \mathrm{ml}$ dan dipindahkan ke tabung reaksi I dengan cara dipipet untuk mendapatkan pengenceran $10^{-2}$. Dari tabung reaksi I dipipet lagi $1 \mathrm{ml}$ dan dipindahkan ke tabung reaksi ke II sebagai pengenceran $10^{-3}$, demikian seterusnya sampai tabung ke III untuk pengenceran $10^{-4}$. Dari setiap pengenceran diambil masing-masing $1 \mathrm{ml}$ larutan secara aceptic dimasukkan dalam dua cawan petri steril. Selanjutnya masukkan PDA steril (suhu $43-46^{\circ} \mathrm{C}$ ) sebanyak $\pm 15 \mathrm{ml}$, ke dalam cawan petri lalu dihomogenkan dengan cara digoyang ke kiri, ke kanan, ke belakang, dan dibiarkan sampai membeku. Setelah media membeku, petri disusun terbalik dalam inkubator bersuhu $25-30^{\circ} \mathrm{C}$ dan diinkubasi selama 24-48 jam. Kemudian dihitung jumlah koloni kapang yang tumbuh pada media agar di cawan petri. Koloni yang dihitung berjumlah 30-300 koloni. Perhitungan

$$
\text { Total koloni kapang }=\sum \text { koloni } \mathrm{x} \frac{1}{\text { faktor pengenceran }}
$$

\section{Prosedur Analisis Angka Lempeng Total (Fardiaz, 1993) yang dimodifikasi)}

Disiapkan larutan $\mathrm{NaCl} \quad 0,9 \%$ lalu dimasukan ke dalam erlenmeyer sebanyak 225 $\mathrm{ml} 10^{-1}$. Masukan larutan $\mathrm{NaCl}$ sebanyak $9 \mathrm{ml}$ ke dalam tabung reaksi yang sudah diberi tanda $10^{-2}$ dan $10^{-3}$, kemudian disterilkan dalam autoclave pada suhu $121^{\circ} \mathrm{C}$ pada tekanan $15 \mathrm{psi}$ selama 1 menit. Disiapkan NA dengan cara ditimbang sebanyak 27,44 gram, dimasukkan ke dalam erlenmeyer kemudian diberi akuades sebanyak $980 \mathrm{ml}$. Selanjutnya homogenkan dengan menggunakan magnetic stirrer kemudian diboil selama 20 menit pada air mendidih dan disterilkan di dalam autoclave pada tekanan 15 psi dengan suhu $121^{\circ} \mathrm{C}$ selama 15 menit. Sampel ditimbang sebanyak 25 gram secara aseptis kemudian dimasukan ke dalam larutan $\mathrm{NaCl} 0,9 \%$ steril yang berisi $225 \mathrm{ml}$ sehingga diperoleh larutan dengan pengenceran $10^{-1}$, dipipet $1 \mathrm{ml} \mathrm{ke} \mathrm{dalam} \mathrm{tabung} \mathrm{reaksi} \mathrm{kedua}$ dengan pengenceran $10^{-2}$ kemudian homogenkan. Selanjutnya ganti pipet kemudian pipet sebanyak $1 \mathrm{ml}$ larutan dalam pengenceran $10^{-2}$ kemudian masukkan ke dalam tabung reaksi ketiga dengan pengenceran $10^{-3}$, kemudian homogenkan. Lakukan seterusnya tergantung berapa kali pengenceran yang akan dilakukan. Dari setiap pengenceran diambil masing-masing $1 \mathrm{ml}$ dan dimasukan ke dalam 2 seri cawan petri steril yang telah diberi kode menurut jenis sampel dan tingkat pengencerannya. Tuangkan $20 \mathrm{ml}$ NA masing-masing cawan petri. Setelah penuangan, cawan petri digoyang-goyang perlahan ke arah kiri, kanan, maju dan mundur dan biarkan media mengeras. Masukkan cawan petri ke dalam incubator yang bersuhu $37^{\circ} \mathrm{C}$ selama 24-48 jam dalam posisi terbalik. Setelah masa inkubasi berakhir, jumlah koloni bakteri yang dihitung pada cawan petri yaitu berjumlah 30-300 koloni. Perhitungan:

$$
\text { Total Bakteri }=\sum \text { koloni } \times \frac{1}{\text { Faktor Pengenceran Per Cawan }}
$$

\section{Prosedur Analisis pH (AOAC, 2005)}

Sampel ditimbang sebanyak 5 gram kemudian ditambahkan akuades $10 \mathrm{ml}$ dan dihomogenkan selama satu menit. Sampel yang sudah homogen dipindahkan ke dalam beker glass $100 \mathrm{ml}$, lalu diukur pHnya menggunakan alat $\mathrm{pH}$ meter. Sebelum $\mathrm{pH}$ meter digunakan, terlebih dahulu dilakukan peneraan dengan menggunakan larutan buffer $\mathrm{pH}$ 7. Nilai $\mathrm{pH}$ sampel adalah nilai yang ditunjukkan oleh monitor digital pada posisi konstan.

\section{Prosedur Analisis Kadar Air (AOAC, 2005)}

Cawan porselen beserta tutupnya yang telah dicuci bersih, dalam keadaan kosong dimasukkan ke dalam oven yang temperaturnya $100-105^{\circ} \mathrm{C}$ kurang lebih selama 1 jam. Cawan dipindahkan ke dalam desikator dan didinginkan selama 30 menit, kemudian ditimbang beratnya. Ke dalam cawan porselen dimasukkan sampel sebanyak 2-3 gram, lalu ditimbang. Cawan porselen yang telah berisi sampel dimasukkan ke dalam oven yang temperaturnya $100-105^{\circ} \mathrm{C}$ selama 3 jam. Pengeringan dan penimbangan dilakukan terus sampai diperoleh berat yang konstan. Setelah diperoleh berat yang konstan, sampel dipindahkan ke dalam desikator dan didinginkan selama 30 menit, kemudian ditimbang. Perhitungan kadar air:

$\frac{(\text { Berat cawan }+ \text { sampel awal })-(\text { Berat cawan }+ \text { sampel akhir })}{\text { Berat sampel }} \times 100 \%$ 


\section{HASIL DAN PEMBAHASAN}

\section{Analisis Kapang}

Berdasarkan hasil pengamatan, pertumbuhan kapang dari hari 0 dan 15 tidak teridentifikasi adanya kapang namun pada hari ke 30 terdapat satu koloni kapang teridentifikasi yang dapat dilihat pada Gambar 1.

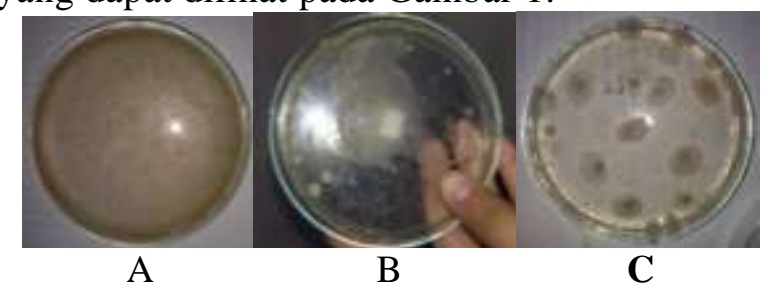

Gambar 1. Pertumbuhan Kapang Ket.:

(A) Pertumbuhan kapang pada 0 hari pada sampel A1B4;

(B) Pertumbuhan kapang pada 15 hari pada sampel A2B4

(C) Pertumbuhan kapang pada 30 hari pada sampel A3B4.

Berdasarkan hasil dari pengamatan menunjukkan bahwa persyaratan mutu yang dikeluarkan oleh Badan Standarisasi Nasional Indonesia (SNI No. 2691-2009) memiliki nilai kapang maksimal $<10^{3} \quad \mathrm{cfu} /$ gram. Hasil penelitian produk ikan kayu asap cair memiliki mutu yang baik sampai penyimpanan ke 30 hari karena total kapang memenuhi standar yang telah ditentukan. Menurut Jay et.al., (2005), pertumbuhan kapang dapat dikenali dari keberadaan miselium yang berkembang pada media pertumbuhan, namun pada hasil penelitian ini menunjukkan bahwa ikan kayu asap cair mengalami pertumbuhan kapang yang lambat sehingga ikan kayu asap cair ini belum nampak atau teridentifikasi kapang hingga pada pengamatan hari ke 3 .

\section{Analisis Angka Lempeng Total (ALT)}

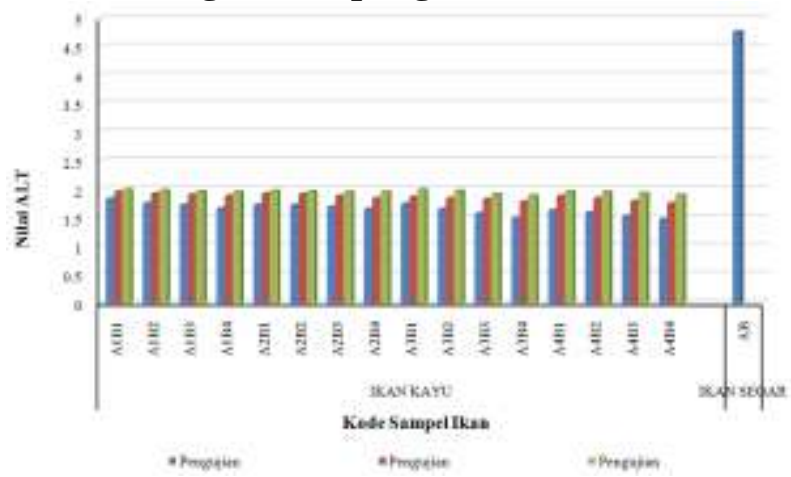

Gambar 2. Jumlah ALT pada ikan kayu asap cair yang disimpan pada suhu ruang.

Berdasarkan data tersebut dapat dilihat bahwa nilai ALT pada ikan segar yaitu $5,8 \times 10^{4}$ $\mathrm{cfu} / \mathrm{g}$, sedangkan pada pengamatan hari ke 0 nilai terendah pada sampel A1B4 yaitu $2,9 \times 10^{2}$ cfu/g dan nilai tertinggi pada sampel A4B1 adalah $6,7 \times 10^{2} \mathrm{cfu} / \mathrm{g}$ pada pengamatan hari ke 15 nilai terendah pada sampel A1B4 yaitu $5,6 \times 10^{2} \mathrm{cfu} / \mathrm{g}$ dan nilai tertinggi pada sampel A4B1 adalah $8,8 \times 10^{2} \mathrm{cfu} / \mathrm{g}$ dan pada pengamatan hari ke 30 nilai terendah pada sampel A2B 4 yaitu $7,7 \times 10^{2} \mathrm{cfu} / \mathrm{g}$ sedangkan nilai tertinggi pada sampel A4B1 yaitu 9,9 $\times 10^{2} \mathrm{cfu} / \mathrm{g}$.

Jumlah bakteri yang tumbuh disebabkan oleh penyimpanan hari ke-0 bakteri baru mulai beradaptasi dengan lingkungannya yang baru, dimana bakteri mampu bertahan hidup walaupun belum dapat berkembang biak (Bawole, et.al., 2017). Aktivitas mikroba juga dipengaruhi oleh penyimpanan, dimana semakin lama penyimpanan produk maka jumlah bakteri semakin meningkat. hasil analisis uji anova menyatakan bahwa lama perendaman dan lama penyimpanan tidak berpengaruh yang nyata terhadap ikan kayu asap cair atau non signifikan tetapi, konsentrasi asap cair berbeda nyata pada produk ikan kayu asap cair atau signifikan.

\section{Bakteri Patogen}

Hasil pengamatan menunjukkan bakteri E. coli, Salmonella sp., Vibrio sp, dan Staphylococcus sp. tidak didapati bertumbuh/keberadaan bakteri. Hal ini menunjukkan ikan kayu asap cair yang direndam asap cair pada suhu ruang yang diteliti menjadi sampel penelitian cukup baik karena hasil uji yang didapatkan adalah negatif, hal ini berarti pengolahan ikan kayu asap cair dilakukan secara higienis sesuai dengan standar (SNI) dan layak untuk dikonsumsi.

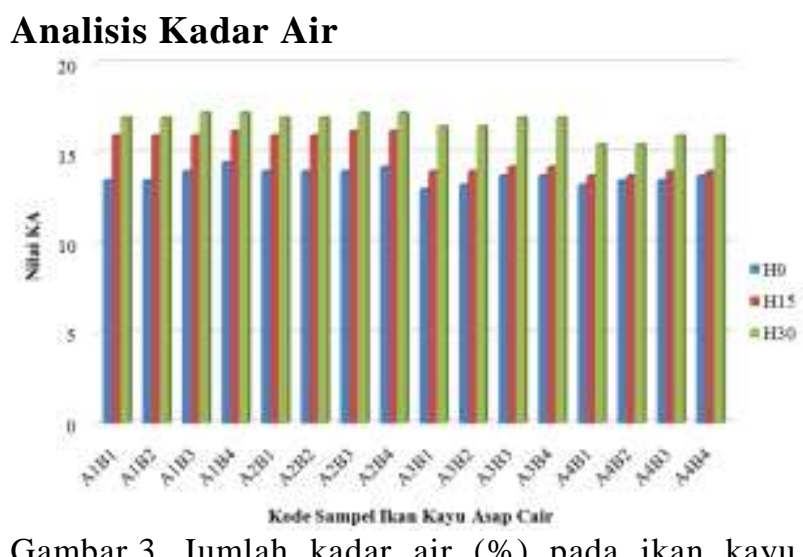

Gambar 3. Jumlah kadar air (\%) pada ikan kayu asap cair penyimpanan suhu ruang.

Hasil data kadar air ikan kayu asap cair penyimpanan suhu ruang di atas memiliki nilai rata-rata kadar air tertinggi adalah sampel A1B4 yang memiliki nilai $17,25 \%$. Sedangkan 
nilai kadar air terendah adalah sampel A3B1 yang memiliki nilai 13\%. Adapun hasil analisis uji anova bahwa konsentrasi asap cair dan lama penyimpanan tidak membuat pengaruh yang nyata terhadap kadar air ikan kayu asap cair atau non signifikan tetapi sangat nyata atau signifikan pada lama perendaman.

Dari hasil tersebut dapat dilihat bahwa, lama perendaman dapat mempengaruhi kadar air ikan kayu asap air tersebut. Seperti yang diketahui bahwa meningkat atau menurunnya kadar air bahan pangan merupakan dampak dari kecenderungan adanya perbedaan kelembaban udara sekitarnya, dengan kata lain kandungan kadar air bahan pangan akan berubah-ubah sesuai dengan lingkungannya. Namun, kadar air ikan kayu asap cair yang rendah akan mempengaruhi berat produk. Menurut Katiandagho 2016, Rendahnya kadar air suatu bahan pangan mempengaruhi masa simpan atau mutu bahan pangan tersebut. Dimana, semakin rendahnya kadar air bahan pangan yang diasap menyebabkan mutu bahan pangan semakin meningkat atau masa simpannya cukup panjang dengan hasil yang didapat, bahwa nilai kadar air yang didapatkan dalam produk ikan kayu asap cair yang disimpan pada suhu ruang memenuhi standar SNI No. 2691-2009 yaitu 20\%.

\section{Analisis pH}

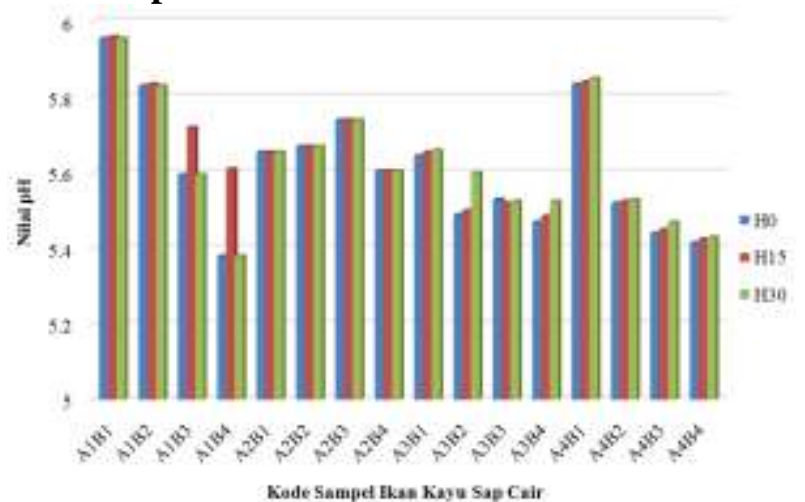

Gambar 4. Histogram Hasil Organoleptik Aroma.

Hasil rata-rata nilai $\mathrm{pH}$ ikan kayu yang direndam dengan asap cair penyimpanan suhu ruang dengan konsentrasi 2, 4, 6 dan $8 \%$ dengan lama perendaman yang berbeda, nilai tertinggi yaitu perendaman 30 menit adalah 5,95 pada konsentrasi $2 \%$ sedangkan nilai terendah yaitu pada perendaman 120 menit adalah 5,38 pada konsentrasi 2\%. Menurut Berhimpon (1974), bahwa tinggi rendahnya nilai $\mathrm{pH}$ dipengaruhi oleh lamanya pengasapan, dimana pada pengasapan yang berlangsung lebih lama, maka unsur asap yang terserap dan melekat pada produk lebih banyak, demikian juga senyawa asam yang terserap juga meningkat. Pengawetan dengan asap cair memiliki $\mathrm{pH}$ bahan pangan sekitar 6,0 dimana pada $\mathrm{pH}$ netral atau bahkan $\mathrm{pH}$ yang lebih rendah atau bahan pangan yang bersifat asam diketahui bahwa pertumbuhan mikroorganisme dapat terhambat (Wisniewski dan Manrer, 1979 dalam Pelokang, 2010). Adapun hasil analisis uji anova bahwa pada produk ikan kayu asap cair menyatakan signifikan dimana konsentrasi asap cair dengan lama perendaman sangat nyata. Hasil tersebut menyatakan bahwa setiap lama perendaman dan konsentrasi berbeda di setiap waktu. Hasil penelitian ini menunjukkan produk ikan kayu asap cair yang disimpan pada suhu ruang memenuhi standar (SNI No. 26912009) yaitu 6.

\section{KESIMPULAN DAN SARAN}

\section{Kesimpulan}

Hasil uji total koloni kapang dan Angka Lempeng Total (ALT) produk ikan kayu (Katsuobushi) asap cair memiliki mutu yang baik sampai penyimpanan ke 30 hari karena total kapang dan ALT memenuhi standar yang telah ditentukan sesuai dengan persyaratan mutu yang dikeluarkan oleh BSN 2009 (SNI No. 2691-2009) yang memiliki nilai $1,0 \times 10^{3}$ cfu/gram dengan hasil Uji anova signifikan.

Bakteri pathogen E. coli, Salmonella sp., Vibrio sp. dan Stapylococcus sp. memiliki nilai negatif selama 30 hari. Berdasarkan analisis kadar air memiliki nilai rata-rata kadar air berkisar antara 13-15,5\%, Berdasarkan analisis memiliki rata-rata $\mathrm{pH}$ yang berkisar antara 5,3-5,9 maka nilai kadar air dan $\mathrm{pH}$ pada penelitian ini memenuhi standar yang telah dikeluarkan oleh BSN 2009 (SNI No. 26912009) yang memiliki nilai kadar air $18 \%$ dan pH 6 dengan hasil Uji anova signifikan.

\section{Saran}

Perlu dilakukan pengamatan lebih lanjut tentang penelitian ini, yaitu untuk bahan perbandingan antara pengujian kapang dan mikroba patogen pada produk ikan kayu (Katsuobushi) yang direndam dengan asap cair pada penyimpanan suhu ruang dengan suhu dingin. 


\section{DAFTAR PUSTAKA}

Association of Official Analytical and Chemistry [AOAC]. 2005. Official Methods of Analysis.

Badan Standarisasi Nasional (BSN). 2009. Ikan Kayu: Produk Perikanan: SNI No. 2691-2009. Jakarta.

Bawole, C.S.F., Mentang, F., dan Dien, H. A. 2017. Penerapan Pengasapan Cair Pada Pengolahan Abon Roa (Hemirhamphus sp.) dan Pampis (Katsuwonus pelamis) dan Mutu Mikrobiologis Produk yang Dikemas Modified Atmospheric Packaging (MAP). Universitas Sam Ratulangi. Manado. Vol 5, No. 1, Januari 2017.

Berhimpon S., 1974., Pengaruh Bahan Pengawet Kimia dan Lama Penyimpanan Terhadap Mutu Ikan Mas (Cyprynus carpio) Asap Yang Disimpan Pada Temperatur Kamar., Thesis., Fakultas Perikanan., Universitas Sam Ratulang-Afiliasi Institut Pertanian Bogor.

Berhimpon S., Dien H.A., Montolalu R.I., 2003., Processing And The Prospect Of Katsuo-bushi (Ikan Kayu) Of North Sulawesi, Indonesia., Journal of International., Presented at The DGHE-JSPS International Workshop on "The Quality Improvement of Traditional Fisheries Products in Asian Region"., Semarang, 25-26 August 2003.

Fardiaz,. S., 1993. Analisis Mikrobiologi pangan. Penerbit PT. Raja Grasida Persada Utama. Jakarta.

Jay JM, Loessner MJ, Golden DA. 2005. Modern food Microbiology. Ed ke-7. Helman DR, editor. New York (USA); Springer.

Katiandagho, Y. 2016. Pengaruh Konsentrasi Asap Cair dan Lama Perendaman Terhadap Mutu Organoleptik dan Isotermi Sorpsi Air (ISA) Ikan Kayu (Katsuobushi). Jurnal. Fakultas Perikanan dan Ilmu Kelautan. Universitas Sam Ratulangi. Manado.

Pelokang D., 2010., Pengaruh Konsentrasi dan Cara Pemberian Asap Cair Terhadap Mutu Ikan Julungjulung (Hemirhampus marginatus) Asap., Skripsi., Fakultas Perikanan dan Ilmu Kelautan Universitas Sam Ratulangi., Manado.

Pszcola DE. 1995 Tour Highlights Production and Use of Smoke House Base Flavors. J Food Tech 49: 70-74.

Rahayu S. 1991. Proses Pembuatan Ikan Kayu (Arabushi). Jakarta (ID): sub Balitkanlut Slipi.

Sutin. 2008. Pembuatan Asap Cair dari Tempurung Kelapa dan Sabut Kelapa Secara Pirolisasi serta Fraksinasinya dengan Ekstraksi. IPB Bogor. 